\title{
Discussion on Clothing Marketing Mode in Network Environment
}

\author{
Jinling Guo \\ Jiangxi Institute of Fashion Technology \\ Nanchang, China 330201
}

\begin{abstract}
With the arrival of information age, network are playing an important role in people's lives. As relation between network and economy is getting closer and closer, marketing is facing a new era called internet marketing. Clothing internet marketing as an important part of internet marketing, is favored by majority of netizens with the popularity of the network. This paper has analyzed the situation of clothing internet marketing, pointed out the problems existed and has put forward some countermeasures as well to improve clothing marketing mode in network environment.
\end{abstract}

Keywords-Internet marketing; clothing; problem;
countermeasure

\section{INTRODUCTION}

Along with economic globalization, relationship between countries is getting closer unprecedentedly. The emerging and popularity of network has helped eliminate constraints on space. People around the world can use internet to communicate with each other freely. Thereafter, information age is coming. With its influence, network and marketing combined with each other to make a new type of marketing called internet marketing which has integrated into people's lives gradually. Driven by the network, there is an unprecedented change in people's way and concept of consumption. Some people who can see business opportunities lay in internet have taken measures to meet the needs of the public, continuously improve market share and maximize the value of their company. As an important part of network marketing, clothing internet marketing will not miss this chance to enter in e-era; it is bound to be successful in "Finger Economy" derived from mouse.

\section{REASONS FOR THE EMERGING OF CLOTHING INTERNET MARKETING}

\section{A. Technical Support Provided by Network}

Internet has provided us with so many miracles, such as things in high speed, wide range, with no time or geographical restriction and rapid feedback and all these can be done anytime we want. Clothing internet marketing has taken the advantage of these characteristics to give out business information, attract potential customers and thus making profits. Meanwhile, the network online payment platform has also made it convenient for online trading between enterprises and customers.

\section{B. Evolution of Consumers' Shopping Psychology and Behavior}

With the popularity of network, both the way and concept of consumption of consumers have changed. People are not just seeking for warmth from clothes, but also fashion and other distinctive features. This is also a kind of "selfrealization" with feeling of "show off". Because of its limit in style and quantity, and serious imitation of brand clothes, traditional store marketing cannot meet consumers' needs in highlighting their features. Fast-paced city lifestyle makes it difficult for people to go to shopping malls. So they need a more convenient way. Advanced information exchanging technology has already met the needs of consumers. They do not need to go out, all they need to do is to move their fingers at home, and then all kinds of clothes will be in front of them. And consumers can also know more about certain clothes through others' feedback on the internet. Evolution of consumers' shopping psychology and behavior has provided a great space for the development of network marketing.

\section{Change of Marketing Environment}

Internet marketing has helped businesses to solve the problem of store renting and has also reduced the capital of inventory. In virtual network environment, businessmen and consumers communicate directly on the internet, saving the cost of sales paid to middlemen. So in this case, price of clothes in network market price is lower than market price. Consumers can buy clothes in good quality with low price online. As consumers are free to evaluate the clothes online, which helps business to collect information in a timely manner and to get consumer trends directly. In this case, they are able to develop products in line with public taste and improve the mall share at the same time. Network market has successfully solved the problem of traditional market which is limit in time and space. So it is possible to work all the time without any limit.

\section{Situation OF Clothing Network Marketing}

In some developed countries, clothing internet marketing has been one of the most important modes for the marketing of brand clothing. The recognition of internet marketing is getting higher and higher. Many clothing enterprises are trying to wide their market, raise their market share, stabilize customer resources, attract potential customers and make their business stronger by this way. 
The number of netizens in China is the largest in the world. "Finger Economy" derived from mouse is growing rapidly. So a large number of netizens means more business chances. China, as a country with $1,300,000,000$ people, is also a large country in clothing production and consumption. Online trade volume is increasing too. Development of online payment technology and arising of Alipay, online banking and cash on delivery all have contributed to the prosperity of internet marketing clothing market. At the same time, during the information era, diversity of logistics system has helped to solve the clothing delivery problems. The combination of payment and logistics has promoted the development of network marketing. However, looking into this industry, China is still in the primary stage of network market, so it still has a long way to go compared with developed countries. Though network consumption is growing, its cardinal number is small. So internet marketing should be further developed.

\section{PRoBlems EXISTING IN CLOTHING INTERNET MARKETING}

As a kind of virtual marketing environment, internet marketing has limitation itself. So along with its development, problems have also arisen.

\section{A. Integrity Issues}

Many people turn to see clothes online, but there are few who buy them in the end. Reasons are as follow: first, consumers are not able to feel clothing and to know its features. Second, consumers see clothes online by pictures, but due to the use of PS technology, there is large difference between that in picture and in reality. This kind of cheating makes it impossible for consumers to buy clothes online. Third, clothing purchased online may be broken during distribution. What's worse, they may receive wrong thing in the end, so they'd prefer to buy it with higher price in store. Fourth, because network is virtual, net users can hide themselves anytime they want. If any side of businessman and consumer is fraud, it is difficult to find someone to be responsible for it.

\section{B. Security Issues}

During online shopping, customers worry about security most. Because virtual network across time and space has provided more chances for criminals. Personal information is unavoidably to be offered by customers during the trade, once leaked, this information can bring damage to customers by utilization by criminals to steal money in their online banks.

\section{Online Fitting Issues}

During their clothing purchase decision, most people believe "Words are but wind, but seeing is believing." So they only buy clothes tried on by them, which cannot be realized during online shopping, because fitting rooms cannot be provided by online store. In this case, if they don't believe in its quality, they will not buy it in the end. What's worse, they might get away from online shopping gradually, which is bad to the development of internet marketing. So it becomes an urgent problem to be solved for the development of clothing internet marketing.

\section{Distribution Issues}

We need to pay attention to the efficency of logistics and distribution system. Because consumers can see pictures of clothes only by online, they want to see real things as soon as possible. Currently the internet marketing distribution system in China including post office and express companies, is far from international level. This might be a reason for why things like "Logistics is too slow" can be seen easily in feedbacks by customers. Slow speed of logistics system has already become a main obstacle for developing clothing internet marketing.

\section{E. After-sale Service Issues}

It is normal for consumers to be willing to change or return goods they have bought. So after-sale service is an issue concerned most by them. Is it convenient to change or return goods? Who will be responsible for its cost and risk? The problems above are main things they consider before buying a product. Being afraid of troubles brought about by bad aftersale services, they will not buy goods online eventually. Therefore, it is vital for online businesses to deal with change and return of goods in a good manner. It will enhance the confidence of consumers in shopping online.

\section{ADVICE AND COUNTERMEASURES FOR CLOTHING INTERNET MARKETING}

\section{A. Take Integrity of Internet Marketing as Guarantee}

Integrity is not only a desire and guarantee to maintain certain values, but also the foundation and prerequisite for the survival and development of clothing internet marketing. The implementation of network integrity policy can resist opportunistic thinking and behavior by some businesses. It can help encourage businesses' efforts in pursuing good relation with consumers and help them get higher reputation and longterm benefits as well.

\section{B. Strengthen on Taking Technical Security Measures}

Safe shopping environment is pursued by all network consumers. Because the development of clothing internet marketing can be speeded up only by trust from customers, businesses generally apply electronic signature certification mode to eliminate consumer confidence crisis. At the same time, network security can be achieved by installment of firewalls and anti-virus software to prevent virus invasion. Consumers should be careful when receiving strange e-mails or information. To prevent their information and money from being stolen, they are not supposed to click it. For cash payment, successful link between clothing sales network and banking system has become a reliable guarantee to ensure secure payments.

\section{Establish Online Fitting System}

It is an indispensable measure to establish online fitting system. Within this system, consumers can build a model by inputting data of their own body. This model can try clothes on, in this way, consumers can get a clear picture of those clothes. However, the present system still needs to be improved, because there is still large difference between model and real 
people. But, we believe with the developing of technology, this system can lead clothing internet marketing to success.

\section{Improve Logistics System}

Rapid development of clothing internet marketing must be based on sound logistics system. It is necessary to combine logistics service with Information Technology to make it intelligent. It is better for clothing online shop to have their own logistics department or cooperate with certain logistics companies. In this case, they can choose the way of distribution according to the variety of clothing, which can help raise the speed of logistics and guarantee the security of goods.

\section{E. Improve After-sale Service}

Good reputation is necessary for the success of a company. Whatever kind of store it is, the only way to success and profits is large amount of customers. Especially for internet marketing, it is better to know psychological demand of customers and bring benefits to consumers by providing good after-sale services. For example, no time limit in return of goods; businesses are responsible for express fees when changing goods with quality problem.

\section{CONCLUSION}

As the network economy is developing rapidly in these days, consumers' demand in modern times cannot be met by traditional materialized sales mode. Clothing internet marketing has more advantages. It will become a main way for shopping by citizens in the near future.

\section{REFERENCES}

[1] Gu Zilong. Clothing Internet marketing Strategy [J]. Heilongjiang Textile.2011.

[2] Zhou Jing, Zhao Qiujin. Research on Situation and Developing Trend of Clothing Internet Marketing [J].Business Economy.2013.

[3] Zhou Zhipeng. Research on the Innovation of Clothing Internet Marketing Strategy [J].Journal of Tongling Vocational \& Technical College.2014.

[4] Xiao Huihui, Wang Xiaojun. Developing Strategy of Clothing Internet Marketing [J].Market Modernization.2010.

[5] Jia Junmin, Shi Yan, Liu Ying. Impact of E-Business Development on Business Marketing [J]. Baoding Vocational and Technical College. 2014 